\title{
Introduction: Remembering the Socialist Past
}

\section{Monika Vrzgulová and Soňa G. Lutherová}

Institute of Ethnology and Social Anthropology,

Slovak Academy of Sciences

\begin{abstract}
This text focuses on qualitative research of the past when it comes to the communist regimes in Europe, particularly Slovakia (as part of former Czechoslovakia). The authors introduce the ongoing research project Current Images of the Socialism as well as its methodological and theoretical frames. They present the findings and challenges, as also articulated during the international conference Memory of the Communist Past (2020) and introduce selected articles included in this special issue.
\end{abstract}

\section{Keywords}

the socialist past; the communist past; biographical interviews; memory; representations

The communist regimes in Europe fell more than 30 years ago. Countries dealing with this experience have started building democratic civic societies. This process has been connected to the effort of coming to terms with the recent communist past. The years immediately following the Velvet Revolution were characterized by a surge in Slovak ethnic nationalism, which contributed to the dissolution of Czechoslovakia on 1st January 1993 and its division into two sovereign states. The newly founded Slovak Republic became a battleground for interpretations of the past, or rather for searching for a "usable past" (Rupnik, Zelionka 2013, 3-25), which could have served as a foundation for the new state. Although the second "post-revolutionary" generation has matured in our country, today this process is still ongoing. We are trying to answer the following question: What does it mean for our present that we, our parents, and grandparents lived under the communist regime?

The current atmosphere in society and the reactions of different social groups to present social, political, economic, and nowadays also pandemic challenges, are influenced by various factors. One of them is the way how the

\footnotetext{
* Monika Vrzgulová (corresponding author), Institute of Ethnology and Social Anthropology, Slovak Academy of Sciences, Klemensova 19, 81364 Bratislava, Slovak Republic; monika.vrzgulova@savba. sk; Soňa G. Lutherová, Institute of Ethnology and Social Anthropology, Slovak Academy of Sciences, Klemensova 19, 81364 Bratislava, Slovak Republic; sona.lutherova@savba.sk.
} 
communist past of the country is constructed, in which images and memories are present in the cultural and communicative memory (Assmann 2016). The values and evaluating attitudes in the current public discourse are the results of the process of how we recollect and reconstruct the past. It also applies to the Communist Party government that ended in November 1989 in Czechoslovakia. As ethnologists and anthropologists, we are used to working with qualitative methods: focusing on (auto)biographical narratives, memoirs, or other ego-documents, the public speeches and rituals by remembrance policies, and on the processing of this period through artistic expression. Our research shows that in families, the awareness and images of socialism are present both in social discourse and intergenerational communication.

After the fall of the Communist regimes in Central and Eastern Europe in 1989, the period of socialism became the subject of scientific research. In several countries, entire scientific institutions and inter-disciplinary teams have focused on the study of socialism and the post-socialist period: e.g., Hannah Arendt Institut für Totalitarismusforschung in Dresden, the team in the Max Planck Institute of Social Anthropology in Halle a/Saale or the experts of the Oral History Centre of the Institute for Contemporary History of the Academy of Sciences of the Czech Republic in Prague. Their research projects have focused on the analysis and interpretation of empirical data about social reality in the context of the communist regime. They observed the daily (lived) reality in the socialist period and clarified the socialist "heritage" in the countries of the former Central and Eastern Europe after the fall of the Communist regime. They followed the implementation process of the new social order and its gradual penetration from the macro-level up to the level of individuals, families, or small social groups' lives. Over the past decades, the research of the social reality in socialism and post-socialism has formed a dynamically developing part of social sciences (Adamski et al. 1999, Buchowski 2001, Burawoy - Verdery ed. 1998, Hann ed. 2002, Roth ed. 2005, Verdery 1996, etc.).

In Slovakia, systematic research into the socialist "heritage," i.e., current social representations of this period in the memory of their participants, is absent. The research on the period of socialism has brought certain outputs in humanities and social sciences (e.g., Bakoš 1999, Bílik 2008, Pešek et al. 2003, Profantová ed. 2012, Zavacká 2005, Londák-Sikora eds. 2009, Stoličná 2015, Salner 2020, etc.). However, there are still considerable gaps in the knowledge about everyday life during this period. Also, the way this era is remembered influences and shapes our present today. 
In the Czech Republic, academic teams (e.g., from the Institute for Contemporary History of the Academy of Sciences of the Czech Republic) have researched the socialist period systematically for almost three decades. They have been using various methods, including the method of oral history. In Slovakia, the reflection of the socialist era in both society and the academic sphere is still not sufficient. Historians and social scientists are searching for appropriate ways to interpret the communist past, dealing with the pitfalls of the totalitarian-historical and nationalistic narratives present in their disciplines (Hudek 2013). The gaps in the academic discourse influence the general discourse in society as well. Slovak society is coping with the question of how to remember the communist past. The reflection is essential for the current young generation, which lacks information that would shape their opinions, images, and representations of the communist regime in their homeland.

\section{Current Images of Socialism}

In 2017, we have started the project Current Images of Socialism ${ }^{1}$. The research team consists of experts from the Institute of the Ethnology and Social Anthropology of the Slovak Academy of Sciences, the Comenius University in Bratislava, Matej Bel University in Banská Bystrica, and P. J. Safarik University in Košice. The project represents unique research using the oral history method and analysis of biographical narrations, with the focus on current representations of socialism ${ }^{2}$, as communicated by the generation of individual personal witnesses. What interested us has not only been how everyday life was like during this period, but also how it is represented, constructed, and talked about in the present. It has not been researched through a strictly historical perspective, but rather from the perspective of social sciences with a focus on contemporary society in Slovakia.

During the interviews, we specifically focused on particular historical periods, processes, and phenomena related to the socialist era in Slovakia. The research methods have enabled us to study the social system from the particular view

1 Our project has been funded from the Slovak Research and Development Agency in 2017 for 4 years. We use the term socialism in an emic sense.

2 There were some steps toward establishing an interdisciplinary research team at that time Institute of Ethnology, Slovak Academy of Sciences in Bratislava. At the beginning of this ambition was an interdisciplinary and international conference in 2004, 15 years after the fall of communist regime. As a follow up, our colleague Zuzana Profantova led several projects as the principal researcher, focused on the communist regime era in Slovakia. The focus, methodological, and theoretical frames of the contributors were very heterogeneous, as shown by the published results of these investigations (Profantova, Z. ed. 2004; 2006; 2009; 2012). Consequently, in our research, we decided to use one particular methodology - oral history - and theories based on this approach. 
of individuals, as well as particular social groups ${ }^{3}$. The biographical interviews represent the source between the macro-, meso-, and micro-levels. The macrolevel is represented by, for example, the State and its legislation; the mesolevel by organizations and interest groups; and the micro-level is created by individuals and their families (Dobbelaeere 1981). The specific interviews might also reflect the experiences of those who are part of macro- or mesostructures, and uncover how they cope with them. This perspective has enabled us to have a look at the stability of these structures from a long-term perspective. This way, they can indirectly point out the tendency to social change. Hence, the empirical basis for the research is represented by human experience, as captured in the recollections and, specifically, experiences from the recent past. The data acquired using interviews in the form of subjective testimonies of the members of selected groups, as well as individual witnesses of the period, reflect the historical-social fact and also the subjectivity of their authors.

\section{The Representations of the Socialist Past}

Our project represents basic and, to a large extent, safeguarding (given the respondents' age) qualitative research focused on the current Slovak society. The importance of our research method does not lie in the factual credibility of the obtained information, but in the ways it depicts the past at present (Crownshaw, Leydesdorff 2008). The project focuses on the collection of data that will show what representations of the everyday life of the socialist period are communicated today in the recollections of personal witnesses ${ }^{4}$ and how they evaluate their current situation and the way they compare it with their past lives in socialist Czechoslovakia. Most oral histories about everyday life in totalitarian regimes focus on the dynamics of the individual vs. state power relationship. The contents of such recollections represent a tool to understand life under the totalitarian regime. We perceive totalitarianism as a social system of an authoritative state which seeks to influence the subjectivity of its citizens through violence and propaganda. The analysis of the subjective experience with a concrete communist regime brings knowledge that reveals the different life strategies and ways of life of individuals and groups under the pressure of the regime. The findings show that despite the efforts made by the totalitarian regime, it fails to completely homogenize the behavior patterns in the entire society (Crownshaw - Leydesdorff 2008, Passerini 2008). Hence,

3 The researchers have been interviewing members of particular professional groups: e.g., teachers or leaders of folk ensembles.

4 We decided to interview particularly people who lived their lives as adults in the Slovak territory in the period 1960-1989. 
the knowledge acquired through research based on the oral history method stops being a fill for the white patches in the official history or the search for ways of how to express an inexpressible experience (Bertaux 1997, Petö 2002). It becomes a tool for understanding the relationship between subjectivity, memory, and totalitarianism and it could help to find a way to create a narrative of the communist past.

The biographical interviews bring images of everyday life, which we understand as immediate reality constructed by people. This reality perceived by an individual has its origin in people's imagination and practices and, at the same time, is maintained and created by employing these (reproduced) images (Berger - Luckmann 1999, 25-44). Another key term regarding our research is memory. The individual memory represents a specific database of experiences, information, as well as feelings, often automatically - one might even say "uncritically" - acquired assessments and judgments (stereotypes and prejudices), which individuals have obtained not only through their own experience, but also indirectly. The person recollecting their memories reinvokes them during the interviews, but in a selective way. While the ability to remember certain events or facts is considered to be a personal quality of an individual, the way they recollect and the things they remember or do not remember and what they overlook or conceal intentionally depends on the social environment: family, friends, professional, local, or other social groups. Every individual memory or remembering is therefore socially dependent and determined (Halbwachs 2009).

The oral history interviews are created in the process of consciously targeted remembering of individuals who are part of major (social) groups. We work with the collectivelsocial memory concept, broken down for our research purposes into the communicative, cultural, and political memory (Kubišová 2014, Assmann, A. 2016, Assmann. 2008).

In society, the memories of the past are present in several forms, which are interconnected and interactive. We can consider the contents of individual, communicative, and collective (nation or state) memory (Assmann, A. 2016, 11), connected with the identification process/identities of their carriers. At the same time, they are the subject of constant social negotiation about what (and in what way) to remember, and what not to talk about (intentionally), as it should rather be forgotten. Memories of the past are part of intraand intergenerational communication. The younger generations acquire (or consciously reject) knowledge and experiences that they didn't survive themselves, and they could become part of their memory and identity (Kaźmierska 2016: 99). The contents of the communicative memory could 
partly become a part of the collective (cultural) memory of a country. Then they are reserved and shared not only orally, but also via materialized media: archival sources, literature, art, monuments, and memorials.

Subjectivity is another concept that is useful regarding analyzing narrations of the socialist past. It represents a field of symbolic activity that entails cognitive, cultural, and psychological aspects (Passerini 1998). Narrations are shaped as spontaneous subjective expressions. They are related to the personal approach, behavior, and language, as well as to other forms of consciousness. At the same time, they are rooted and reflected in the identity-making process of an individual. Regarding this, the term subjectivity entails not only the epistemological dimension but also the essence and meaning of politics in the life of man. Therefore, it is appropriate to ask: with what intensity and in what ways does pressure (of an authoritarian or totalitarian regime) occur in the sphere of subjectivity? In our research project, we are also seeking the answer to the following question: what makes the oppressed accept their oppression in the cultural and psychological sense to such a degree that they praise it and prefer it to fight for change (Passerini 1998, 54-55)? This question might be particularly relevant with regard to the analysis and interpretation of the interviews and narrations about life in socialist Slovakia.

Witness testimonies (recollections) represent individual images of historic events and can be understood as mental representations, which can be communicated and subsequently shared by a certain range of people from a social group as public representations (Sperber 1996). The social group and its environment are filled with representations about the past (e.g., about life during the period of socialism), both mental and public. Each group member has many mental representations that create their knowing. Through their communication outwards, i.e., by disclosing them, individual/mental representations become public. A part of mental representations, communicated recurrently and spread within the group as public representations, has the potential to become a part of cultural representations that have been commonly shared for several generations. Cultural representations form the subset of an entire set of mental and public representations that have long been present in the given social group (Sperber 1996). The focus of our interest within the project is on mentallindividual and public representations of socialism and the process of their (non-)communication within the public discourse.

However, there is one concept that we consider crucial when doing, analyzing, and interpreting interviews. It is represented by the term intersubjectivity. This concept relates to the interaction between the two subjectivities - an interviewer and an interviewee. In every interview, subjectivity and intersubjectivity are 
in play. Hence, when we rethink the interview as a historical document we ought not to forget that it is the result of a three-way dialogue: the narrator with himself or herself, between the interviewer and the narrator, and between the narrator and cultural discourses of the present and the past. This means that individual memory stories are shaped by the intersubjective relationships that are present in the interview. In this sense, what we as researchers listen to are narrative constructions of memories of experiences actively created for an audience. Thus, the story that is told is a version (or rather a recreation) of the past created within a specific context and for a specific purpose (Abrams 2016, 59-60).

While focusing on representatives of a particular group of professionals - teachers, the project's principal investigator Monika Vrzgulová used the abovementioned concepts in her analysis and interpretation. The first and foremost priority deserves to be allotted to the intersubjectivity, and the subsequent priority might be allotted to identity and memory. ${ }^{5}$ The biographical narratives, which were acquired through the means of the oral history method, constitute memories - individual reconstructions of the past. They are determined by the subjectivity, self-presentation of the narrator, and their identity (or identities). At the same time, a second subject comes into this process, the researcher. Their mutual relationship created during the interview also influences the content of the acquired memory (Abrams 2016:54; Vrzgulová 2019). At the same time, the intersection of these two subjectivities (the interviewee and the interviewer) is shaped by yet another factor: it is being played out in the context of certain public discourse. The historical era that is at the center of the interviewee's narrative, has a specific place and character in the discourse. We need to keep this in mind while the interviewee remembers these evaluations and assigned qualities. These three factors need to be looked upon and re-considered during the whole research process (intersubjectivity, identity, and memory): from acquiring the interview, through its processing, to analysis and interpretation. The focus on everyday life, work, and family of the witnesses of socialism (in this case professional group of teachers) brings the answer to the following questions: What did it mean to be a teacher during socialism in Slovakia (1948-1989) from an individual perspective? What kind of challenges had to be faced, how were the personal values and the pressure of the communist ideology brought in balance? What is the interviewee's attitude to the then governing Communist Party and its representatives, respectively, and did the

5 She presented her work-in-progress at the 14th SIEF Congress in Santiago de Compostella in the panel: Current Images of Socialism: https://www.siefhome.org/congresses/sief2019/panels.shtml\#7228. The name of her presentation was "Teachers in socialism: authorities of regime servants?" 
interviewee mention their membership in the Communist party? How was the professional reputation of the teachers in society at that time?

Collected biographical narratives are examples of how interviewees try to construct a meaningful and coherent life story that allows them to feel satisfied with their lives. To support their interpretations of their own lives, the partners in the research mentioned the most significant or important stories, events, and moments. The acquired data so far show examples of surviving and self-realizing strategies of the people living in a society under the communist regime. It is a social memory of the representatives of a profession, which was utilized as an ideological power tool for the indoctrination of younger generations in society. Besides active support of the regime, negotiation with power, formal approval, or bending of the rules are also parts of these memories. While analyzing them, it is interesting and crucial to focus on the agency of the witnesses of the totalitarian regime, as it emerges as " a structuring factor in the shaping of oral histories, whether it be in terms of interpretative achievements of those testifying, the struggle for the autonomy in the "grey zone" of life under the totalitarian regime, or more fundamentally the struggle to retain transcendent values under the regime" (Crownshaw-Leydesdorrf 2008, xiii).

\section{The Memory of the Communist past}

In 2020, we have decided to present the preliminary results of the research project, but also to discuss our particular themes, approaches, methodological challenges, and dilemmas at an international forum. We organized the interdisciplinary conference Memory of the Communist Past, a three-day online live event (owing to the COVID-19 pandemic). ${ }^{6}$ More than 40 scholars from 11 countries (Slovakia, Czech Republic, Austria, Germany, Italy, Netherlands, Poland, Romania, Russia, Slovenia, and Ukraine) and various research fields (ethnology, social anthropology, history, social psychology, and political science) have presented their research in twelve thematic panels. The contributions covered the material from Central-European and EasternEuropean regions and focused on the following themes: individual narratives and the transmission of individual memories in families over the generations; social representations and public recollections; cultural memory and political discourse (politics of memory); and others. The conference also included a panel on particular methodological and ethical questions and challenges of qualitative research of memories of the socialist past.

6 For three days, we have streamed more than 40 presentations, live discussions, and two lectures by invited key-note speakers. The program, book of abstracts, as well as individual presentations are available at the project website: https://www.obrazysocializmu.net/conference. 
Gelinada Grinchenko (V. N. Karazin Kharkiv National University, Ukraine) opened the conference with a thought-provoking piece on the particularities of post-socialist oral history in Europe. The oral histories have become a powerful intellectual tool to analyze the socialist past. However, the representations of the socialist past (or rather pasts in plural) have been weaponized in the postsocialists ideological battles. They have been used as tools for legitimizing the agency of various social (and political) agents in the present (KhanenkoFriesen - Grinchenko 2015). The socialist ideologists had promoted an ideological image of a socialist society as a uniform whole. But the actual everyday reality of the people was heterogeneous, and these alternative experiences and memories are reflected in the postsocialist representations of the socialist past (as mentioned by Gelinada Grinchenko in her opening lecture of the conference). The tension between the private and public life resulted in specific everyday strategies of people during socialism, and these influence the memories of the witnesses even today (Zavacká, 2005). They are formed by past and present notions, ideals, and aspirations. This is reflected in the collective, as well as individual, memories, which are being transferred in the families over the generations.

The principles and structures of the socialist society shape social relations up to the present times. A second key-speaker of the conference, Michal Buchowski (Adam Mickiewicz University, Poznan and European University Viadrina, Frankfurt/Oder), elaborated on the way current social groups and discursive practices relate to the past pre-1989 social hierarchies and discourses. He describes this through the battle for cultural hegemony and political domination through the creation and reification of the categories of Us and Them in the post-socialist Polish society.

One of the members of our project (and a co-editor of this issue) Soňa G. Lutherová presented research on the way individual memories of socialism are transferred and represented in families. In their narrations, the witnesses recreated their memories about everyday life during socialism and presented them to their (grand-)children. The data has shown that the individual stories and personal memories about the socialist era were generally rather positive. This is not uncommon for the biographical narratives, as they are usually constructed as representations of "normal" life. Also, they are often

7 As part of the research, Lutherová (along with the principal investigator of our project Monika Vrzgulová) asked 10-18 year-old children to choose a photograph from the socialist era, which attracts their attention in the family photo albums. They were further instructed to ask their parents/grandparents to tell them a story and memories related to the photograph. In the end, the children were to rewrite the narrations and send them to the investigators along with the photographs. This created a specific opportunity for the witnesses of socialism (parents/grandparents) to present their memory of the past. 
unconsciously created with the idea of how "good life" is supposed to be (Gullestad 2004). In narrations acquired by Lutherová, when individual experiences were confronted with aspects of life during socialism that were perceived as negative, the witnesses often resorted to humor or irony. Witnesses often used the act of biographical narrative as an opportunity to explain their past stances to their (grand-)children. To do this, they approached the image of the past through comparison with their current everyday life and experiences. Sometimes, they rationalized their past decisions; especially those that might have been perceived as questionable or even controversial by their grand(children). Throughout the analysis, one aspect remained clearthe research data created a specific mixture of representations of the socialist past by both the parents/grandparents (as the witnesses) and children/ grandchildren (as the listeners and writers of the narrations). Consequently, this enabled Lutherová to study the way by which memories of the socialist past are transmitted in the families and interpreted by the members of different generations.

Most of the members of our project (Adam Wiesner, Luba Volanská, Kamila Koza Beňová) participated in the panel on methodology, epistemology, and ethical issues in the research on memories of the socialist past. With the growing time gap and with fewer and fewer testimonies of the actual witnesses of the socialist era available, the problem of how to design the research on the current representations of the communist past becomes particularly important. This unequivocally complicates the oral historical research on socialism and has concrete theoretical and methodological implications. At the same time, it calls for innovative approaches throughout the research process. To strengthen the collaborative aspect in the interview-making, Adam Wiesner appropriated the "Not-Knowing Approach" from Collaborative Therapy in an oral history setting. His goal was to create a liberating space for mutual spontaneous engagement between the researcher and his partners in the research. Lubica Vol'anská did her research literally "at home." She focused on the biographical narratives of the inhabitants of one apartment building, where she lived as a child. This has made her both an insider and outsider and it brought up specific tensions and challenges in relationship with her informants. Kamila Koza Beňová studied people living their adult lives in a small industrial town in central Slovakia. In her research, she analyzed the way stories and memories of the individuals living in the periphery relate to the collective narrative of the past. At the same time, she focused on the subjectivity of the researcher as a tool for understanding the subjectivity of the others. 
The final discussion, which concluded the last day of the conference, also revolved around the key epistemological and methodological questions. The invited experts Milena Benovska Sabkova (South West University "Neofit Rilski", Blagoevgrad, Bulgaria) and Gelinada Grinchenko joined the members of our project (Monika Vrzgulová, Soňa G. Lutherová, Lubica Volanská, and Adam Wiesner, all from the Institute of Ethnology and Social Anthropology, Slovak Academy of Sciences) in the discussion at the virtual round table. They discussed the wider aspects of research on socialism in post-socialist countries, its current situation, and future perspectives. The conference has brought up a valuable panoramic view of different perspectives of socialism. As the discussants pointed out, most of the participants of the conference were young people (Ph.D. students and post-docs) without direct experience and memories of the socialist era. This provides us with an opportunity for new theoretical and methodological impulses in the field of anthropology of socialism. It is a much-needed and yet challenging task. Many papers with a comparative perspective on different countries focused on the politics of memory. They have shown a clear tendency towards the politics of oblivion that is present throughout the Central and Eastern European regions. The discussion was finalized by questioning the ways of constructing the socialist past not only in the academic discourse but also in the media. Regarding this, there is a strong need to disseminate academic knowledge in the wider social practice - for example in the educational system. As concluded in the discussion, the key challenge is to bring the multiperspective in the ways we remember the communist past in the society.

\section{From Memories to Representations, and Beyond}

The papers in this issue thematically follow the areas of interest covered during the conference as well as in our project. They also present a varied set of innovative methodological approaches and methods used to study the memories of the socialist past.

Saskia Weise-Pötschke focuses on the memorial sites as public places that are material representations of the past. In her research, she analyzed the meaning of the Stasi detention center for the particular group of witnesses - former inmates of the center. In her paper, she is analyzing their personal feelings and thoughts written down in the visitor books. Through this, she sheds light on the way they perceive their (often traumatic) memories concerning this place and the experience of re-visiting it. Also, she uncovers the meaning and significance of this place of individual and social remembering of the socialist past. 
Naum Trajanovski looks at the memory policies and public discourse regarding Skopje as a "City of solidarity". This symbolic labeling originates in the aftermath of the devastating earthquake in the early 1960s, which was followed by long-term reconstruction of the city. It was launched by the Yugoslavian government and endorsed by the international community. Through the analysis of media texts, museum archives, and political discourse, Trajanovski analyzes the way "solidarity" functions in the local memory up until the present day, as it became a platform for political struggles and discursive wars on various levels.

In her paper, Anna Tonelli elaborates on the ideals, norms and values of communism, as presented in the curricula of the Frattocchie School, the political educational institution for cadre leaders in Rome, Italy. The pupils studied the historical materialism and the history of the Bolshevik party. Also, they were indoctrinated by the notions of group identity, collectivity, and other theoretical and practical values of communism. These notions and ideals formed generations of young people (despite their ideological excesses) and prevailed after the school was closed in 1993.

Focusing on the current popular cultural phenomenon of the historical TV series, Victoria Sukovata follows the way they represent the public, political, and cultural mood regarding the common communist past. Following the impact of the change of the historical narrative after the fall of the USSR, she pays attention to the coexistence of various conflicting memories in the society. Searching for and adapting the historical themes in post-soviet cinematography and television should have functioned as a mobilizing and unifying element. According to Sukovata, the resulting nostalgia for the socialist past is the reaction to the low quality of social relations today, as well as to the materiality and pragmatism as the currently prevailing attitudes towards life. She points out that the discussions on the socialist past have not only a political but also a moral dimension.

The last two papers in this issue direct the attention to coming to terms with the communist past in Slovenia from the perspective of two scientific fields, focusing on both, macro- and micro-levels of society.

According to historian Tjaša Konovšek, the process of reconciliation, which has initialized the turning point of 1989, has been long-lasting and is still ongoing. Its goal is to reconcile with the communist past, injustice, and crimes, in a way that would cease to divide the Slovenian society. The author analyzes particular phases of state politics of remembrance in the last 30 years, and the attempts to institutionalize the memory of the communist governance. She 
follows the moments and turning points, which brought about the changing political representations and ideas.

Katarina Možina and Katarina Kompar Erzar are focusing on the trauma recovery and post-traumatic growth of one three-generational family from a psychological perspective. They contemplate the consequences of intimidation and silencing of the victims in the communist regime. The resulting fear and anger influenced whole generations of society. Their case study follows how individual generations undergo the healing process and extricate from the negative impacts of the trauma. This insinuates a way out not only for one family but for society as a whole.

The monothematic issue brings a varied sample of current themes, concepts, sources and methods, acquired by the practitioners of social sciences and humanities in their research on the socialist past and its present representations. The papers reveal the construction of - individual and social, or (in other words) cultural and political - memories of communist regimes in the countries of Central, Southern, and Eastern Europe. They uncover the specificities as well as common features of remembering socialism. It remains clear that the memories are diverse and still very much alive in the discourse as well as in the collective and individual (un)consciousness. This does not regard only the actual witnesses of the era, but members of younger generations as well. Consequently, the critical reflection of their perceptions is an indispensable prerequisite to move forward.

\section{References}

Abrams, Lynn. Oral History Theory. Second edition, London and New York, Routledge 2016.

Adamski Wladyslaw et al. (eds.). System Change and Modernization. East-West in Comparative Perspective. Warsaw, IfiS Publishers 1999.

Assmann, Aleida Shadows of Trauma: Memory and the Politics of Postwar Identity. New York, Fordham University Press 2016.

Assmann, Jan Communicative and Cultural Memory. In: Erll, Astrid - Nünning, Ansgar (eds.). Cultural Memory Studies: An International and Interdisciplinary Hand-Book. Berlin, New York 2008, pp.109 - 118.

Bakoš, Ján Umelec v klietke. Bratislava, SCCA 1999.

Berger, Peter L. - Luckmann, Thomas. Sociálni konstrukce reality. Pojednání o sociologii védèní. Brno, CDK 1999.

Bílik, René. Duch na retazi. Sondy do literárneho života na Slovensku v rokoch 1945 - 1989. Bratislava, Kalligram 2008.

Buchowski, Michal. Rethinking Transformation: Anthropological Perspective on Postsocialism. Poznań, Wydawnictwo Humaniora 2001. 


\section{Journal of Nationalism, Memory \& Language Politics 15(1)}

Burawoy, Michael. - Verdery, Katherine (eds.). Uncertain Transition. Ethnographies of Change in the Post Socialist World. Lanham 1998.

Crownshaw, Richard - Leydesdorff, Selma. Introduction to the Transaction Edition. in: Passerini, Luisa (ed.). Memory and TotalitarianismTransactions Publishers. New Brunswick (USA) and London (UK) Second printing 2008, pp. vii - xix.

Dobbelaere, Karel. Secularization: A Multi-Dimensional Concept, in: Current Sociology, 1981.29, 1 - 216.

Gullestad, Marianne. Imagined Childhoods: Modernity, Self and Childhood in Autobiographical Accounts, in: ISF Paper, 2004. No. 12.

Halbwachs, Maurice. Kolektivni pamět. Praha, SLON 2008.

Kaźmierska, Kaja. Biographical and Collective Memory: Mutual Influences in Central and Eastern European Context, in: Małgorzata Pakier and Joanna Wawrzyniak (eds.). Memory and Change in Europe. Eastern Perspectives. New York, Oxford: Berghahn Books 2016, pp. 96-114.

Khanenko - Friesen, Natalia - Grinchenko, Gelinada. (eds.). Reclaiming the Personal: Oral History in Post-socialist Europe. Toronto, ON, University of Toronto Press 2015.

Kiczková, Zuzana et al. Pamät žien: O skúsenosti sebautvárania v biografických rozhovoroch. Bratislava 2006.

Londák, Miroslav - Sikora, Stanislav (eds.). Rok 1968 a jeho miesto v našich dejinách. Bratisava, Veda 2009.

Kubišová, Zuzana. Kolektivní pamět a národní identity. in: Maslowski, Nicolas - Šubrt, Jiří. et al. Kolektivní pamět. K teoretickým otázkám. Praha: Karolinum, 2014, pp. 81 - 111.

Lipták, Lubomír. Komunistická diktatúra, in: Mannová, Elena (ed.) Krátke dejiny Slovenska. Bratislava: AEP 2003, pp. 300 - 320.

Pešek, Jan et al. Aktéri jednej éry na Slovensku. Bratislava 2003.

Profantová, Zuzana (ed.). Small History of Great Events in Czechoslovakia after 1948, 1968 and 1989. Bratislava, VEDA 2006.

Profantová, Zuzana (ed.). Naratívna každodennost'v kontexte sociálno-historickej retrospektivy. Malé dejiny velkých udalostí, III. Ústav etnológie SAV, Bratislava 2007.

Profantová, Zuzana. et al. Hodnota zmeny - zmena hodnoty. Demarkačný rok 1989. Bratislava, Ústav etnológie SAV, Národopisná spoločnost' Slovenska 2009.

Profantová, Zuzana. et al. Žili sme v socializme I. We Used to Live in Socialism I. Bratislava, Zing Print 2012.

Profantová, Zuzana. Žili sme v socializme II. Helena. We Used to Live in Socialism II. Helena: A Biographical Approach to the Ethnology of Daily Life. Bratislava, 2015

Roth, Klaus (ed.). Arbeitswelt - Lebenswelt. Facetten einer spannungsreichen Beziehung im Sozialismus und Postsozialismus. Freiburger Sozialanthropologische Studien, Band 4, Münster: LIT Verlag 2006.

Rupnik, Jacques - Zielonka, Jan. Introduction: The State of Democracy 20 years on: Domestic and External Factors, 'Special Section' Democracy in Central and Eastern Europe: The State of the Art, in: East European Politics\& Societes 27:1 (February 2013), pp. 3-25. 
Salner, Peter. Socialism and the Jewish Community in Slovaki, in: Studia Etnologiczne $i$ Antropologiczne, 2020, No. 20, pp. 1-11, https://journals.us.edu.pl/index.php/SEIA/article/ view/10813)

Sperber, Dan. Explaining Culture: a Naturalistic Approach. Cambridge: Blackwell 1996.

Stoličná, Rastislava. Socializmus na tanieri. Možnosti a praktiky stravovania obyvatelstva Slovenska v rokoch 1948-1989. Bratislava, Veda 2015.

Vaněk, Miroslav - Krátká, Lenka (eds.). Příběhy (ne)obyčejných profesí. Česká společnost v obdobi tzv. normalizace a transformace. Praha, Karolinum 2014.

Vaněk, Miroslav (ed.). Obyčejni lidé...?! Pohled do života tzv. mlčici vétšiny. Životopisná vyprávèni príslušnikù dělnických profesi a inteligence. Praha, Karolinum 2009.

Vaněk, Miroslav-Mücke, Pavel. Velvet Revolutions. An Oral History of Czech Society. Oxford, Oxford University Press 2016.

Verdery, Katherine. What Was Socialism and What Comes Next. Princeton Univ. Press 1996.

Vrzgulová, Monika. The oral history interview - a relationship and space of trust. in: Slovenský národopis/Slovak Ethnology, 2019, Vol. 67, No. 4, pp. 430-440, DOI: https://doi. org/10.2478/se-2019-0025.

Zavacká, Marina.Kto žije za ostnatým drôtom? Oficiálna zahraničnopolitická propaganda na Slovensku, 1956-1962: Teórie, politické smernice a spoločenská prax. Bratislava, Veda 2005.

Zavacká, Marina. V čom sme to vlastne žili? Mýty budovania komunizmu. in: Krekovič, Eduard, Mannová, Elena, Krekovičová, Eva (eds.), Mýty naše slovenské. Bratislava: Premedia, 2013, pp. 224-237.

This study emerged as part of the APVV 160345 project Current Images of Socialism, and the collaboration of both guest editors on this volume was part of their work in this project. 